\title{
From Open Access to Open Science: innovation in scholarly
}

\author{
communication
}

\section{Do Acesso Aberto ao Open Science: inovação na comunicação acadêmica}

\author{
Wouter Schallier \\ Hernán Santa Cruz Library, ECLAC/United Nations \\ wouter.schallier@cepal.org
}

\begin{abstract}
Open Science is often presented as the overarching "umbrella" of Open Access and Open Data, amongst others. In this article, we start from the finding that, for many years, Open Access to knowledge and research has been a generally accepted principle in Latin America. The Open Access movement in Latin America can even be considered a global pioneer with regards to raising the visibility of research output through channels outside the traditional scholarly communication model. In terms of Open Data, the LEARN project (2015-2017) has come to the conclusion that, while important challenges remain in terms of actual implementations of policies, institutions in Latin America (and the Caribbean) are generally well aware of the importance of research data management $(\mathrm{RDM})$ and seem to accept the general principle of openness of data from publicly funded research. This makes Latin America, in principle, well positioned to move towards Open Science, as a way to rethink the traditional scholarly communication model, and explore more innovative, transparent and inclusive ways to exchange research output on a regional and global level.
\end{abstract}

Keywords: Open Access. Open Data. Open Science. Latin America. Scholarly communication. LEARN project. Innovation.

Resumo: A Ciência Aberta é frequentemente apresentada como o "guarda-chuva" abrangente de Acesso Aberto e Dados Abertos, entre outros. Neste artigo, partimos da constatação de que o acesso aberto ao conhecimento e à pesquisa tem sido um princípio geralmente aceito na América Latina por muitos anos. O movimento do Acesso Aberto na América Latina pode ser considerado o pioneiro global em termos de aumentar a visibilidade da produção da pesquisa por meio de canais que não formam parte do modelo tradicional de comunicação acadêmica. No que diz respeito aos Dados Abertos, o projeto LEARN (2015-2017) concluiu que, embora ainda persistem importantes desafios em termos de implementação de políticas, em geral as instituições na América Latina (e no Caribe) estão cientes da importância da gestão de dados de pesquisa (RDM) e parecem aceitar o princípio de abertura dos dados de pesquisas financiadas com fundos públicos. Isso faz com que a América Latina, em princípio, esteja bem posicionada para avançar em direção à Ciência Aberta, como uma maneira de repensar o modelo tradicional de comunicação acadêmica e explorar formas mais inovadoras, transparentes e inclusivas de trocar resultados de pesquisa em nível regional e global.

Palavras-chave: Acesso Aberto. Dados Abertos. Ciência Aberta. América Latina. Comunicação científica. Projeto LEARN. Inovação. 


\section{Introduction}

When we talk about Open Access to knowledge and research, we observe that the principle of "openness", in the sense of public access to knowledge without economic barriers, has been a generally accepted principle for many years in Latin America. A wide range of institutional, national, regional and thematic digital repositories have been crucial instruments to make research output available to a broad audience. Regional platforms such as SciELO, Redalyc and Latindex have been there from the very start of the Open Access movement and have been true pioneers in re-inventing traditional scholarly communication, demonstrating that publicly funded research can and should be made available as widely as possible. Several countries in Latin America (Brazil, Argentina, Peru and Mexico) have a national legislation that provides a framework for Open Access. There is also regional harvester of digital repositories called La Referencia which links with the global COAR Repositories. In brief, Open Access can build on a long and stable tradition in Latin America (BABINI, 2013).

Institutions in Latin America and the Caribbean with limited financial resources have also been provided, through initiatives such as Research4Life, access to a set of traditional journals that are normally hidden behind high paywalls. Research4Life is a public-private partnership that provides low and middle-income countries with temporary free or relatively low cost access to international scientific journals through four programmes: HINARI (health), AGORA (agriculture), OARE (environment), ARDI (innovation) and GOALI (global justice). However, it needs to be emphasised that, while for some institutions this means that they have de facto free access to research information, this is definitely not an Open Access policy. Quite the opposite actually, since the objective of the commercial publishers involved in this programme is precisely to charge the institutions at "normal" rates once they have more financial resources.

\section{Traditional scholarly communication as a source of inequality and exclusion}

Here we touch one of the main problems of the traditional scholarly communication model, an issue which the global Open Access movement has not been able to solve. Indeed, it has consolidated it to some degree. For many years, the Open Access movement has been trying to get cheaper or even free access to so-called "core" journals. These "core" journals are mainly owned by five large publishers (Taylor and Francis, Wiley, SAGE, Springer and 


\section{IRIS}

From Open Access to Open Science: innovation in scholarly communication

Wouter Schallier

Elsevier), all from the Global North. This commercial oligopoly has led to significant price increases which the academic community has been fighting against for many years. But it has also lead to a canonization of journals considered "core" (or "mainstream" or even "world class"). The recognition and the validation of the work of researchers from all over the world has been systematically biased towards comparisons based on this arbitrary and unrepresentative set of "core" journals. As a consequence, a large variety of research outputs produced globally and published outside this canon have been systematically ignored as "peripheral" (GUÉDON, 2008). Finally, it has led "to a situation where research that is of vital importance to national development priorities has been marginalized" (CHAN, 2014).

The tension between "core" and "peripheral" is also reflected in the erroneous usage of the impact factor as a standard for measuring the quality of a journal (or even worse of an article). This is why the impact factor has been - rightly - under so much pressure lately. Academia is exploring more adequate ways to measure the quality of research output, and one of the the latest formal statements in that sense, is the San Francisco Declaration on Research Assessment. The San Francisco Declaration stipulates, amongst others, the following principles: journal based metrics should be eliminated, research should be assessed on its own merits rather than on basis of the journal in which it is published, and new indicators of significance and impact should be explored. In 2015, the Metric Tide advanced the idea of "responsible metrics" making the case for a fundamental change in scholarly communication, and particularly for a more transparent and more representative quality assessment.

In brief, the Open Access movement has made important breakthroughs in terms of guaranteeing broader access to research output, and most research institutions in Latin America and in the Caribbean have benefited from this. The Open Access movement in Latin America can be considered a global pioneer for successfully increasing the visibility of research output through alternative and innovative channels of scholarly communication, mainly repositories and thematic portals. However, the global Open Access movement has not (yet) been able to eliminate some of the most striking sources of inequality and exclusion in scholarly communication, such as the division between "core" and "peripheral" journals, and the erroneous usage of the impact factor as a quality standard of individual research output.

\section{More innovative and inclusive ways of sharing research output}


During the last few years, something interesting has been happening which appears to provide a new dimension to Open Access. Aside from rejecting ongoing price increases, research institutions from all over the world seem to no longer be willing to accept the principle of publicly funded research being hidden behind a paywall. Many researchers are committed to serve the public good, and want to disseminate their research results as widely as possible, without economic barriers. The University of California, for example, recently published its Declaration of rights and principles to transform scholarly communication, consisting of 18 guiding principles for negotiations with publishers during journal license renewal. Negotiations between the big publishers and consortia of research institutions in several countries (Netherlands, Germany, Sweden, United States) have stalled. More and more research institutions seem to question the whole issue of access to the expensive "core" publications.

Traditionally, journals were considered to be facilitators of research. Nowadays, however, they are no longer automatically considered the most effective option for the advancement of science. Researchers are looking for new and flexible forms of scholarly communication (blogs, open notebooks etc.) that allow them to achieve broader impact in a shorter time. New infrastructures are being explored that allow for a more representative, inclusive and immediate exchange of knowledge and research output. In that view, the division between core and peripheral literature is becoming less prevalent (CHAN, 2017).

For a long time, access to information and knowledge has been considered fundamental to all aspects of human development. As an example, access to information and knowledge is very prominent in the United Nations Sustainable Development Goals, and particularly in the ones related to eradication of poverty (1), quality education (4), infrastructures and innovation (9), inclusive societies and access to justice (16), and partnerships (17). The call for openness has gained a new momentum in society and political discourse. Openness is seen as a means to support development, transparency and innovation. Openness is expected from researchers because it allows citizens to exercise their "right to science" (SHAVER, 2010).

In this context, where a traditional scholarly communication model is being considered expensive, ineffective and exclusive, where internet technology allows for a more innovative, flexible and inclusive exchange of research output, and where society expects transparency and participation from publicly funded research, it is no surprise that research institutions from all over the world are increasingly interested in Open Data and Open Science. 


\section{Data driven research and the need for policies}

Research institutions are realizing that the amount of data produced is growing very fast, and that these are important assets for which institutional policies are needed. In 2013, the League of European Research Universities (LERU) published a Roadmap for Research Data, providing a "guide for research-intensive universities, indeed for any European university, which wants seriously to engage with the potential and challenges of data-driven research". Thanks to the financial support of the European Union (grant agreement 654139), the LEARN project (2015-2017) could actually use this Roadmap to raise awareness on research data management (RDM) amongst research institutions in Europe and in Latin America and the Caribbean.

A rather pragmatic definition of research data which is used in the context of the LEARN project is the following: "All data which is created by researchers in the course of their work, and for which the institution has a curational responsibility for at least as long as the code and relevant archives/record keeping acts require, and third-party data which have originated within the institution or come from elsewhere" (LERU, 2014). The main objective of the LEARN project was to assist research institutions in Europe, Latin America and the Caribbean, with the implementation of research data management policies.

When the LEARN project started, several countries in Latin America (Argentina, Mexico, Peru) had already national legislation establishing a framework for research data. Other countries (Brazil, Chile) had important RDM initiatives (ANDAUR, 2016). However, very few institutions in the region had actually implemented RDM policies. There was not much clarity on the roles and responsibilities for RDM on the institutional level. There were several interesting RDM projects, often involving international partners from outside Latin America and the Caribbean, but there was very little exchange of RDM experiences within the region. In Latin America the main issue was the usability of research data, while in the Caribbean accessibility seemed to be the biggest challenge.

Through a regional conference in Santiago de Chile, two local workshops in Port of Spain and Rio de Janeiro, and around 10 virtual workshops, the LEARN project aimed to raise awareness on the need for institutional RDM policies as well as the requirement for dialogue between different stakeholders (senior management of research institutions, funding agencies, researchers, librarians, ICT staff etc.) on an institutional, national and regional level. 
A Toolkit with RDM case studies from Europe and Latin America and the Caribbean was produced, as well as a model policy, a survey for institutions to assess their readiness for RDM. These tools can be used and customized by any institution interested in RDM. A significant effort was expended on building and maintaining a LEARN network consisting of more than 600 stakeholders in the region.

To date, the number of implemented institutional RDM policies in Latin America and the Caribbean remains low, but important progress can be seen in the number of events organized on RDM and in the number of institutions actively exploring how to implement RDM policies. This is particularly the case in Argentina, Brazil, Chile, Colombia, Mexico, Peru, and Trinidad and Tobago. Also, there seems to be much more discussion and exchange of experiences amongst stakeholders in the region.

The question of the openness of research data was also tackled by the LEARN project. It is assumed that open access to research data is an enabler of high quality research, a facilitator of innovation and high quality research. The suggestion of the LEARN project was that research data produced from publicly funded research, should be open by default ("open whenever possible, closed whenever needed"). This was based on the understanding that there can be good reasons (privacy, patents etc.) for not sharing some research data. A similar position, seeking to create a default to open, but recognising limitations, can be found in the Concordat on Open Research Data, from the UK: "any restrictions to openness of research data must be justified and justifiable".

\section{From Open Access and Open Data to Open Science}

Open Science is defined by the FOSTER project as "the movement to make scientific research, data and dissemination accessible to all levels of an inquiring society". (As has been pointed out by many, a better term (in English) for Open Science would be: Open Scholarship, since science usually refers to exact and applied sciences, while Open Science is clearly used in a broad sense.) Open Science is often presented as the overarching "umbrella" of Open Access, Open Data, Open Notebooks, Open Software, Open Hardware and Citizen Science. Open Science does not just cover publications and data, but extends to any research output (notebooks, software etc.) where this output is made available to other researchers and indeed to any citizen. The Association of European Research Libraries (LIBER) considers Open Access as the first step to enabling Open Science, implying that every step forward 


\section{IRIS}

From Open Access to Open Science: innovation in scholarly communication

Wouter Schallier

towards more Open Access (and more Open Data), is a direct contribution to more Open Science. In that vision, Open Science is the strategy, and the other Open's are the tactics.

As we have seen previously with Open Access and Open Data, Open Science is an answer to the call from inside academia that scholarly communication can be done in a more effective, more transparent and more inclusive way. Some may question this inclusiveness, since Open Science has the most significant uptake in Europe, with nearly half of the documents sourced being produced by European stakeholders (ALBORNOZ, ET AL., 2018). Nevertheless, as could be observed at the latest FSCI 2018 Summer School in San Diego, California, Open Science is also gaining field in North America, Canada, and Latin America and the Caribbean.

Open Science is a way to address the demands from society to make the whole research process (and particularly the way public funds are spent) more transparent, and to let private sector and citizens contribute to the research process. This is the idea of a "knowledge commons" (ALBORNOZ, 2017) where every individual has the ability to manage, access and produce knowledge that concerns them, and where everyone is a potential knowledge producer.

What are the benefits of Open Science? Apart from increased transparency and participation, other benefits directly related to the research process are frequently mentioned, such as: reduced cost of data collection, avoidance of duplication of effort, resulting in increased efficiency, more rigorous and higher quality of research (RESEARCH INFORMATION NETWORK, 2010). In the context of the European Open Science Cloud (EOSC), Open Science is also named as a way "to allow people and firms from all sectors to take full advantage of the benefits of innovation" (ALBORNOZ, 2018). In doing so, Open Science is considered a driver of innovation and socioeconomic growth. Finally, Open Science is often mentioned as a response to global development challenges, through increased and more inclusive international collaboration.

\section{Conclusion}

What kind of changes does Open Science imply for researchers and research institutions? How can libraries support the implementation of Open Science in research institutions? How do Open Access and Open Data lead to Open Science? What would we want to see in terms of infrastructure, tools and partnerships? Open Science is about maximizing visibility of 
From Open Access to Open Science: innovation in scholarly communication

Wouter Schallier

research output for all. This requires a "publication, metrics and rewards system [that] can ensure that knowledge is made available to the widest audience possible" (CHAN, ET AL, 2014): new, more inclusive, equal, diverse and collaborative ways of sharing research output, from anywhere in the world, based solely on the value and merits of the individual research output, and not on the reputation of a journal or a publisher and outside the traditional formats of journals and monographs (NEYLON, 2010). It requires awareness of biases and the willingness to take distance from habits and procedures that do not strictly belong to the essence of research and scholarly communication. And finally, as with Open Access and Open Data, Open Science is not just a vision, it also needs to be reflected in institutional policies and legal frameworks that take into account the specific regional, national and institutional context.

\section{Disclaimer}

The views expressed in this article are the personal views of the author, and do not necessarily reflect the views of ECLAC/United Nations.

\section{Acknowledgments}

The author would like to thank Cameron Neylon, Mírian Ramirez, Claudia Vilches and Héctor Aracena for their helpful comments and improvements to this article.

\section{References}

ALBORNOZ, D. The rise of big publishers in development and what is at stake: a development perspective. 2017. Disponível em: < http://knowledgegap.org/index.php/2017/09/20/the-rise-of-bigpublishers-in-development-what-is-at-stake/>. Acesso em: $1^{\circ}$ ago. 2018

ALBORNOZ D., ET AL. Framing power: tracing key discourses in open science policies. In: ELPUB, 2018, Toronto. Anais... Toronto. Disponível em: <10.4000/proceedings.elpub.2018.23>. Acesso em: $1^{\circ}$ ago. 2018

ANDAUR, G. Research data management in Latin America and the Caribbean: an overview. 2016. Disponível em: < http://learn-rdm.eu/en/research-data-latin-america/>. Acesso em: $1^{\circ}$ ago. 2018

ANDAUR, G.; SCHALLIER, W. Raising awareness on RDM and engaging stakeholders in Latin America and the Caribbean. In: LEARN Toolkit of Best Practice for Research Data Management, p. 35-38, 2017. Anais... Disponível em: <http://learn-rdm.eu/wp-content/uploads/RDMToolkit.pdf>. Acesso em: $1^{\circ}$ ago. 2018. 
BABINI, D. Open access initiatives in the Global South affirm the lasting value of a shared scholarly communications system. In: London School of Economics and Political Science Impact Blog, 2013. Disponível em: < http://blogs.lse.ac.uk/impactofsocialsciences/2013/10/23/global-southopen-access-initiatives/>. Acesso em: $1^{\circ}$ ago. 2018.

CHAN, L. Confessions of an open access advocate (interview). 2017. Disponível em: $<$ https://ocsdnet.org/confessions-of-an-open-access-advocate-leslie-chan/ $>$. Acesso em: $1^{\circ}$ ago. 2018.

CHAN, L.; ET AL. Centering the knowledge peripheries through open access: implications for future research and discourse on knowledge for development. In: SMITH, M. L., REILLY, K. M. A. Open development: networked innovations in international development. 2014. Disponível em: <http://hdl.handle.net/1807/44099>. Acesso em: 1º ago. 2018.

GUÉDON, J. C. Open access and the divide between "mainstream" and "peripheral" Science. 2008. Disponível em: <http:// eprints.rclis.org/10778/1/Brazil-final.pdf Last>. Acesso em: $1^{\circ}$ ago. 2018.

NEYLON, C. What would scholarly communications look like if we invented it today? 2010. Disponível em: < http://cameronneylon.net/blog/what-would-scholarly-communications-look-like-ifwe-invented-it-today/ Last>. Acesso em: $1^{\circ}$ ago. 2018.

RESEARCH INFORMATION NETWORK UK. Open Science Case studies. 2010. Disponível em: <http://www.dcc.ac.uk/projects/open-science-case-studies Last>. Acesso em: $1^{\circ}$ ago. 2018.

SHAVER, L. The right to science: ensuring that everyone benefits from scientific and technological progress. European Journal of Human Rights, v. 4, p. 411-430, 2015. Disponível em:

<http://dx.doi.org/10.2139/ssrn.2564222>. Acesso em: $1^{\circ}$ ago. 2018.

WILSDON, J., ET AL. The metric tide: report of the independent review of the role of metrics in research assessment and management. 2015. Disponível em: <10.13140/RG.2.1.4929.1363>. Acesso em: $1^{\circ}$ ago. 2018.

Data de submissão: 03-08-2018

Data de aceitação: 30-08-2018 